\title{
Hydro-Geoelectrical Investigation for the Potential of Underground Water Storage along the Lower Reaches of King Abdullah Canal-Deir Alla Area/Jordan
}

\author{
Hani Al-Amoush ${ }^{1 *}$, Elias Salameh², Marwan Al-Raggad ${ }^{2}$ \\ ${ }^{1} \mathrm{Al}$ Al-Bayt University, Mafraq, Jordan \\ ${ }^{2}$ Jordan University, Amman, Jordan \\ Email: *hani1@aabu.edu.jo
}

Received March 12, 2012; revised April 14, 2012; accepted May 19, 2012

\begin{abstract}
In this article the potential stoarativity of groundwater in the alluvial deposits along the King Abdullah Canal (KAC) in Deir Alla-Sulikhat area is studied. In this study geological, geo-electrical and Hydro-geochemical methods were used with the aim of storing some water of the Canal during water excess times in the underground to be extracted for use as drinking source for human during shortages in the Canal water and in emergency causes of Canal water pollution. The results show the existence of appropriate underground space in the alluvial deposits for water storage and that the water/ water and water/rock interactions are also be minimal and will not present and detriment to the different groundwater bodies. Implementing groundwater artificial recharge in the Jordan Valley area to create storage for King Abdullah Canal (KAC) water will enhance the drinking water supply during the dry season and it will also serve as a reserve for emergency causes, especially pollution accidents in King Abdullah Canal (KAC), such as those taking place almost every year.
\end{abstract}

Keywords: Jordan Valley; Geo-Electrical; King Abdullah Canal (KAC)

\section{Introduction}

According to preliminary investigations rechargeable aquifers are found in the Jordan Valley (JV) area [1,2]. Such aquifers can accommodate several millions of cubic meters of recharge water and serve as storage reservoir. Worldwide, surface waters are contaminated or are exposed to contamination by human actions and natural circumstances. Surface waters in semiarid areas should, in general not be directly channeled into treatments plants for use in drinking purposes, but are first stored in underground reservoirs, after that they are extracted for treatment and use in drinking purposes [3]. King Abdullah Canal (KAC) (The East Ghor Canal) (Figure 1) and its irrigation network is considered the most important water project in Jordan, it is a concrete lined gravity canal $110 \mathrm{~km}$ long fed by $1 \mathrm{~km}$ diversion tunnel running underneath the mountain between Yarmouk River and the village of Adassiya. KAC transfers water from the Yarmouk River to the south at the shores of the Dead Sea and Irrigates 230.000 dunum (23,000 hectare) [4]. The water sources of the KAC are from Yarmouk River, at the international Jordan border with Syria, Mukheiba wells, the peace conveyer water from Israel, and the

${ }^{*}$ Corresponding author. southern tributaries which flow within Jordanian territories [3]. Presently, 60 to 70 million cubic meters per year $(\mathrm{MCM} / \mathrm{Y})$ of water are pumped from the KAC to Amman with the provision for treatment at Zai plant, located between Deir Alla, the water intake site and Amman (Figure 1) [3]. During the last 24 years of the operation of Deir Alla-Zai water supply scheme water pumped from King Abdullah Canal (KAC) have suffered of different water pollution problems, which in 1987 and 1998 affected human health with rigorous consequences for the water supply scheme from KAC and for the different water agencies such as the Water Authority of Jordan and the Jordan Valley Authority. Since 1998 several water pollution events affected KAC water and catastrophes were only averted in last moments. In many years since its operation the KAC was not able to supply the necessary water amounts due to decreased flow, especially during the summer months when drinking water is badly needed. The risks of contamination and drought are still present and can at any time negatively affect the water supply of Amman and the other cities, which partly depend on Deir Alla-Zai scheme for their drinking water, although the Ministry of Water and Irrigation has installed early warning systems on the KAC to warn against pollution. In general, storing surface water un- 
derground has many advantages over storing it in surface reservoir dams or Canals such as KAC. This study aims at finding underground storage aquifers for the surface water of KAC along the lower reaches of KAC, using geological mapping, vertical electrical soundings and hydro-geochemical investigation.

The water of the KAC according to the suggested scheme sees for to store water in the aquifers along the Canal when water is in excess (winter times) and pump it when need arise or when the Canal water can not be used directly as a source of drinking waters due to pollution.

\section{Description of the Study Area}

The area of study is lies in the middle part of Jordan Valley, and it is situated between the coordinates [203,000 - 212,000] E, [1,170,000 - 1,194,000] N, according to Palestine Grid (PG) coordinates system (Figure 1). It covers an Area of $110 \mathrm{Km}^{2}$. Topographically; The Jordan Valley extends from Lake Tiberias at an elevation of 212 meter below sea level (mbsl) southward to the Dead Sea at an elevation of 420 mbsl. The Jordan Valley is surrounded from both sides by high, steep escarpment with difference in elevation between the valley floor and the surrounding mountains of $1200 \mathrm{~m}$ going up to $1400 \mathrm{~m}$ [1]. The Climate in the Jordan Valley is classified as of semiarid type. Average annual rainfall ranges from 250 $\mathrm{mm}$ in the northern part of Jordan Valley to $75 \mathrm{~mm}$ at its southern part in dry years, these values may reach 650 $\mathrm{mm}$ in the north and $250 \mathrm{~mm}$ in the south at wet years $[1,5]$. The mean maximum annual temperature in the study area is 30 degree Centigrade; the mean minimum annual temperature may reach only a few degrees Centigrade. The relative humidity ranges between $30 \%$ during hot summer days and $70 \%$ in cold winter days $[1,5]$.

The main features of the Jordan Valley area are the relatively flat terraces found on both sides of the Jordan River, which constitute the bed of the valley. Several major side wadis and one river are dominating the study area such as Zerqa River (the second largest river in the country in term of its catchments area), Wadi Rajib, Wadi Kufranja and Wadi Sulikhat (Figure 1) [6].

\section{Geological Setting}

The geological formations composing the study area are discussed below. Figure 2 shows simplified geological map and Table 1 lists the litho-stratigraphic successions in the area of study.

Following is a brief description of the different geological formations occupying the Jordan Valley floor in the study area $[7,8]$.

\subsection{Jordan Valley Group (JV1)}

This Group consists of well cemented conglomerates with

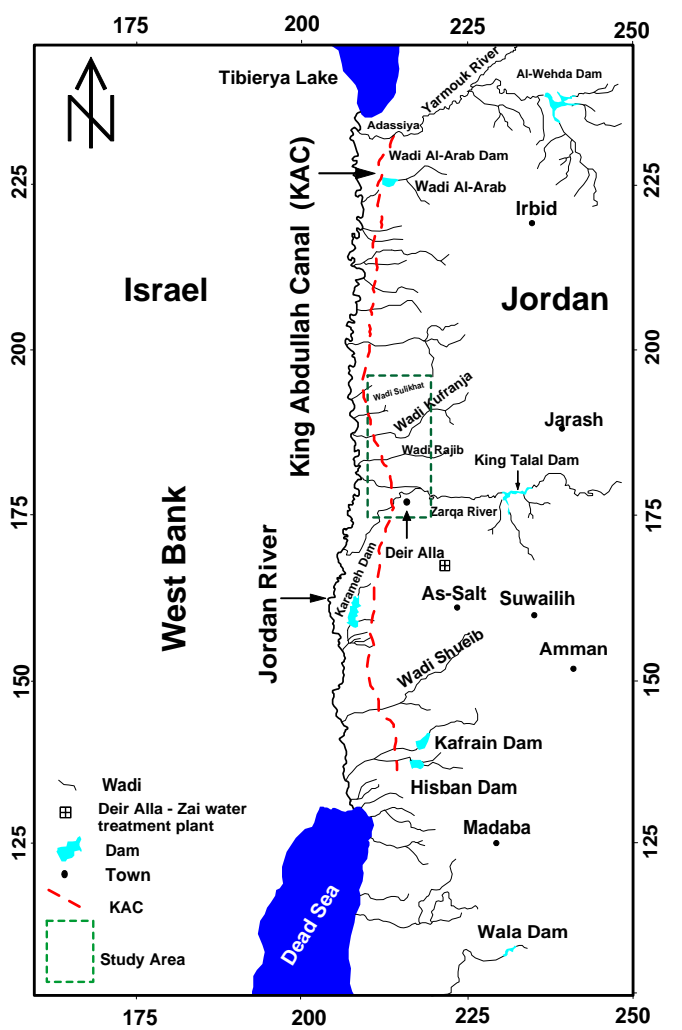

Figure 1. Location map of the study area and KAC route.

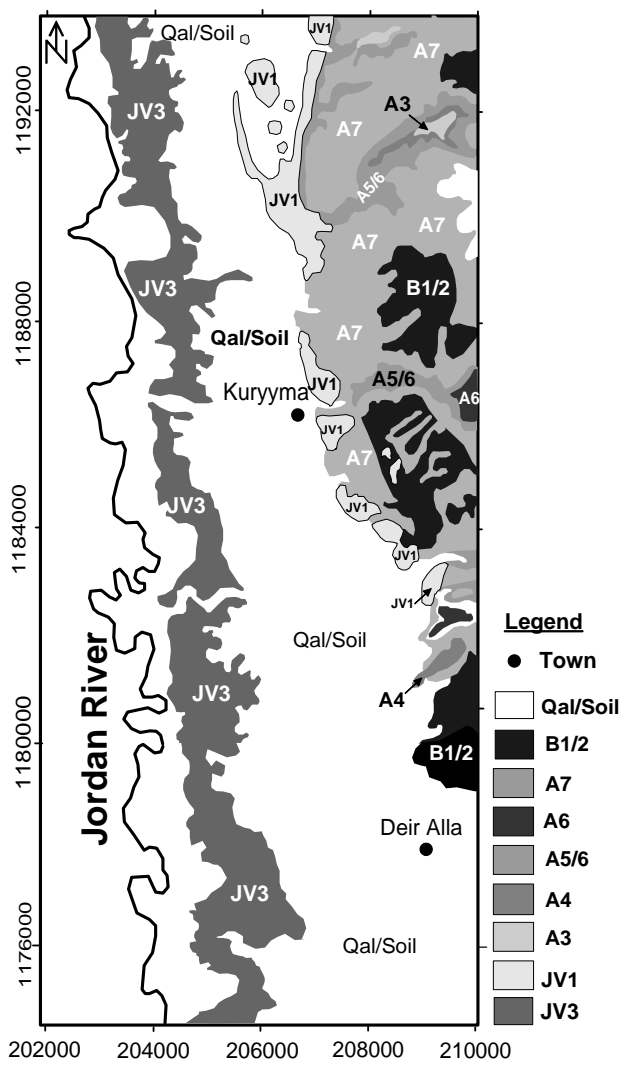

Figure 2. Simplified geological map of the study area (Modified after $[7,8])$. 
Table 1. Litho-stratigraphic successions in the study area after $[7,8]$.

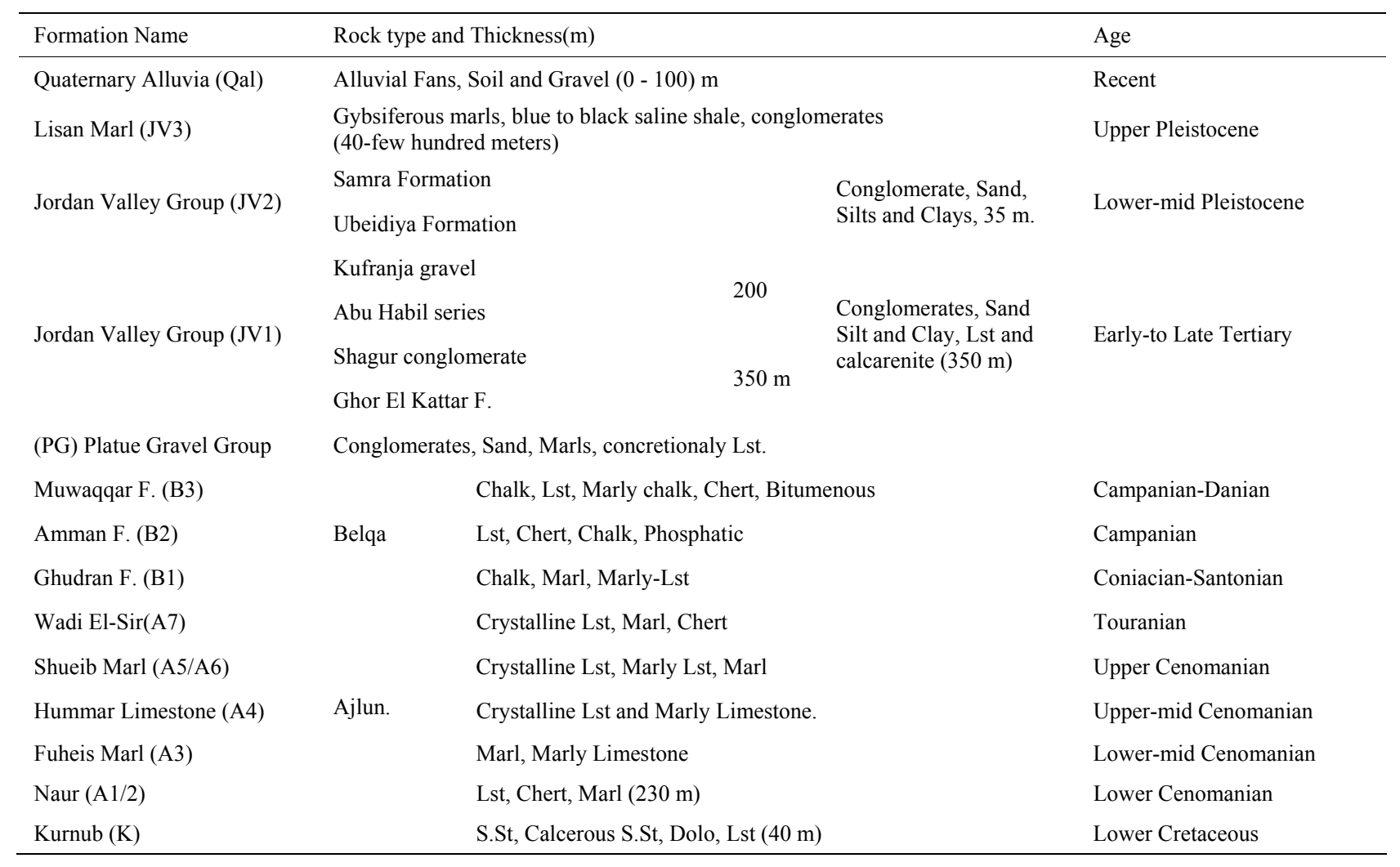

low porosities and permeabilities, its deposition was associated with the tectonic movements that formed the rift valley. It includes materials of fluviatil and lacustrine origin. This group lies unconformably over older systems and is overlain by Quaternary soil, sand and gravel [7]. This Group consists of the following formations.

\subsubsection{Shaqur Formation}

This Formation is composed of well-cemented calcareous sandstone, conglomerate blocks up to one meter in diameter, limestone and travertine. It overlies pre-Quaternary rock units and is highly dissected by N-S Pleistocene faults with beds steeply dipping towards west [9]. The exposures of this Formation usually show deformations indicating that they have been subjected to disturbances prior to the deposition of the overlying formations. According to [10] the age of this Formation is Upper Pliocene to Early Pleistocene.

\subsubsection{Ghor El-Katar Formation}

This Formation is composed of steeply dipping layers of alternating conglomerates, sandstones, marl and marly clays. The total thickness of this Formation is about 300 $\mathrm{m}$ decreasing northwards to reach $75 \mathrm{~m}$ at $2 \mathrm{~km}$ SE Kuryyma [11]. This Formation has a very limited occurrence in the study area; the age of this Formation is suggested to be of Lower-Middle Pleistocene [12].

\subsubsection{Abu-Habil Formation}

This Formation crops out near Abu-Habil Village (15 km north of Deir Alla). It consists of hard conglomerate and partly pisolitic limestone with a thickness that may reach $100 \mathrm{~m}$ and unconformably overlies the Ghor El-Kattar Formation and has a Middle Pleistocene age [10].

\subsubsection{Kufranja Gravel Formation}

According to Bender [12], this Formation is of Middle Pleistocene age. It consists of poorly consolidated gravels with red argillaceous matrix and Early Paleolithic artifacts. It correlates with Naharayim Gravels in the south of Lake Tiberias.

\subsection{Jordan Valley Group (JV2)}

The Group consists of conglomerates, sand, silts and clayey marls and overlies the JV1 with a total thickness of some $100 \mathrm{~m}$. It corresponds to another tectonic activity of the Jordan Valley formation and overlies the JV1 with a certain unconformity. Its occurrences in the study area are very limited. The age of this formation is suggested to be lower to middle Pleistocene age [7,10]. It includes Ubeidiya and Samra Formations (Table 1).

\subsection{Lisan Marl Formation (JV3)}

The Formation covers more than $70 \%$ of the Jordan Val- 
ley area. The thickness of this Formation is about $300 \mathrm{~m}$ and it belongs to Early to Late Pleistocene [10]. The upper part is called Lisan Marl facies and consists of alternating fine to medium particles of marl and clay with friable chalk, silt and gypsum [10]. The lower part is composed of dark gray and greenish marls with few sand layers [10]. It occurs mainly on the Jordan River meandering plain and in the underground of alluvial covered flood plain. Within the Formation, in its eastern part many gravel and sand beds occurs representing deltaic or alluvial fans deposits interfingering with the Lisan Formation.

\subsection{Quaternary Alluvium (Qal) and Alluvial Fans}

These refer to unconsolidated colluvials developed along the course of the major wadis. They usually overlie the Lisan Formation (JV3) and are composed of lenticular beds of gravels, sands and calcareous clay. They are derived from older formations exposed in the adjacent catchment areas. The gravels are usually composed of limestone, dolomites, chert, basalts boulders and pebbles with a matrix of sand, silt and clay [10]. The gravel beds are usually very pervious, the calcareous clays and clay beds are fairly impervious, the gravel beds are more abundant near the side wadis of the foothills, while the silt and sands occur more abundantly at the fringes of the fans towards the Jordan River course. The groundwater occurring in the alluvial fans of the major side wadis accounts for more than $80 \%$ of the available fresh groundwater in the Jordan Valley [6]. The thickness of alluvial fans as encountered by drilling and geo-electric sounding may exceed $100 \mathrm{~m}$ [2].

\section{Hydrogeology}

The study area is composed-in terms of hydro-geological aspects - of four different aquifers systems these include: Zerqa Group aquifer ( $\mathrm{Z}$ ), Kurnub sandstone aquifer (K), Upper Aquifer Complex (A1-A6 and A7/B2), and Jordan Valley (JV1) Group. Table 2 lists these aqui- fers systems along with their hydro-geologic classification.

\section{Jordan Valley Group Aquifer (Shallow Groundwater Aquifer)}

The Jordan Valley Group thickly fills the rift valley and forms the wide valley floor. This group can be divided into three main units, which are from older to younger: consolidated/cemented conglomerate layers of about 100 $\mathrm{m}$ in thickness, conglomerates and alternating marl, sand, gravel layers of about $350 \mathrm{~m}$ in thickness and alternating marl, clay, chalk, silt and gypsum layer of about $300 \mathrm{~m}$ in thickness (Lisan Formation, JV3) [13]. The aquifer in the Jordan Valley is formed by the middle unit which is intercalated with sand and gravel layer (Sand/Gravel Aquifer). The Specific Capacity of Sand/Gravel Aquifer in the southern part of the Jordan Valley ranges from 100 to $300 \mathrm{~m}^{2} /$ day in average [13].

The upper zone represents the shallow aquifer which extends along the Jordan Valley floor and consists of alluvial fans and other recent sediments. The recent sediments inter-finger with the salty, clayey deposits of the ancestors of the Dead Sea, like Lisan Lake which, tens of thousands years ago extended northward beyond the present shores of Lake Tiberias [12]. This shallow aquifer has a good potential with rather good water quality. However, it deteriorates towards the west due to the presence of Lisan beds responsible for an increase of the salinity of about 1500 to $2500 \mu \mathrm{S} / \mathrm{cm}$, the permeability of the shallow aquifer ranges between $6.5 \times 10 \mathrm{e}^{-4}$ to $1.3 \times$ $10 \mathrm{e}^{-2} \mathrm{~m} / \mathrm{s}$ with an average value of $6.6 \times 10 \mathrm{e}^{-3} \mathrm{~m} / \mathrm{s}[13]$.

\section{Data Acquisition, Processing and Interpretation}

121 Vertical Electrical Resistivity Soundings were conducted in the area of study along N-S profiles (Figure 3(a) and Figure 3(b)), using an ABEM CAMPUS GEOPULSE Ltd. resistivity meter. It is a digital signal enhancement device incorporating a micro-processor that gives the resistance reading in $\Omega, \mathrm{m} \Omega$ or $\mu \Omega$ and capable

Table 2. Simplified hydro-geological classification of the rock units [13].

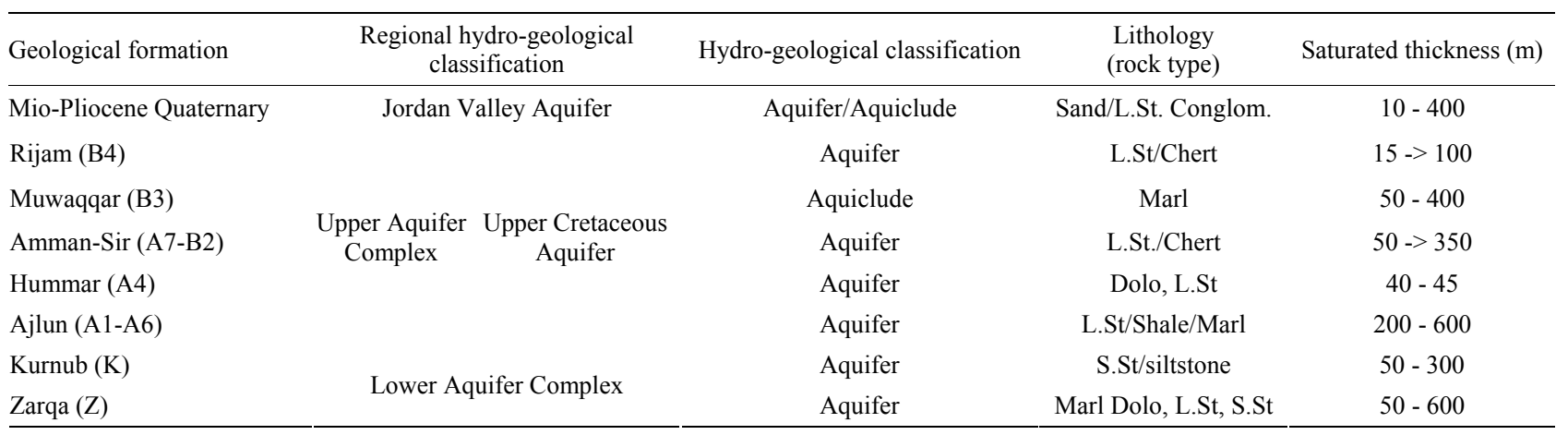




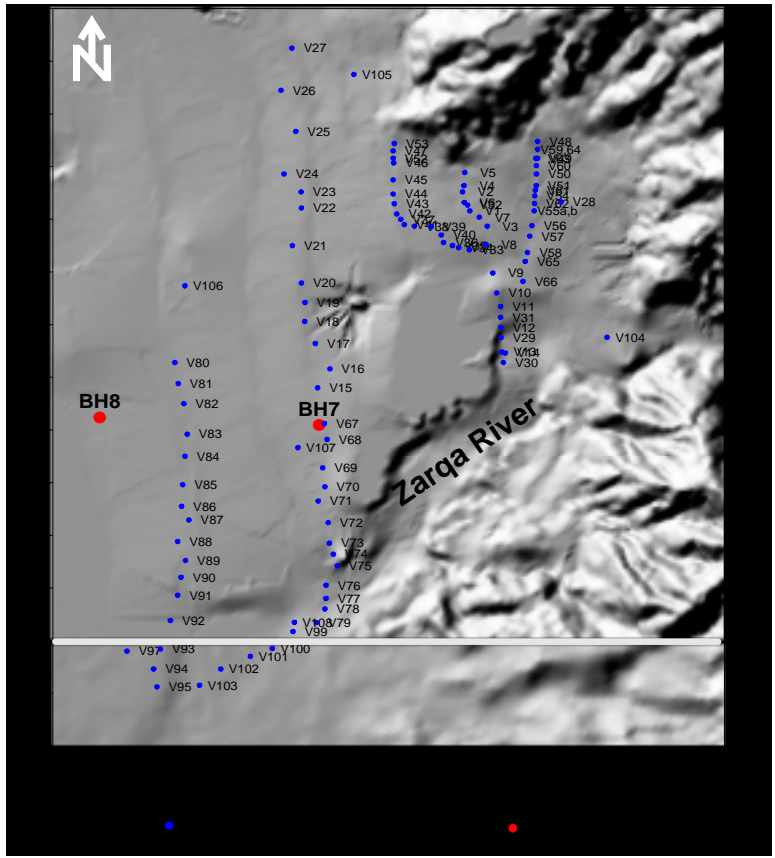

(a)

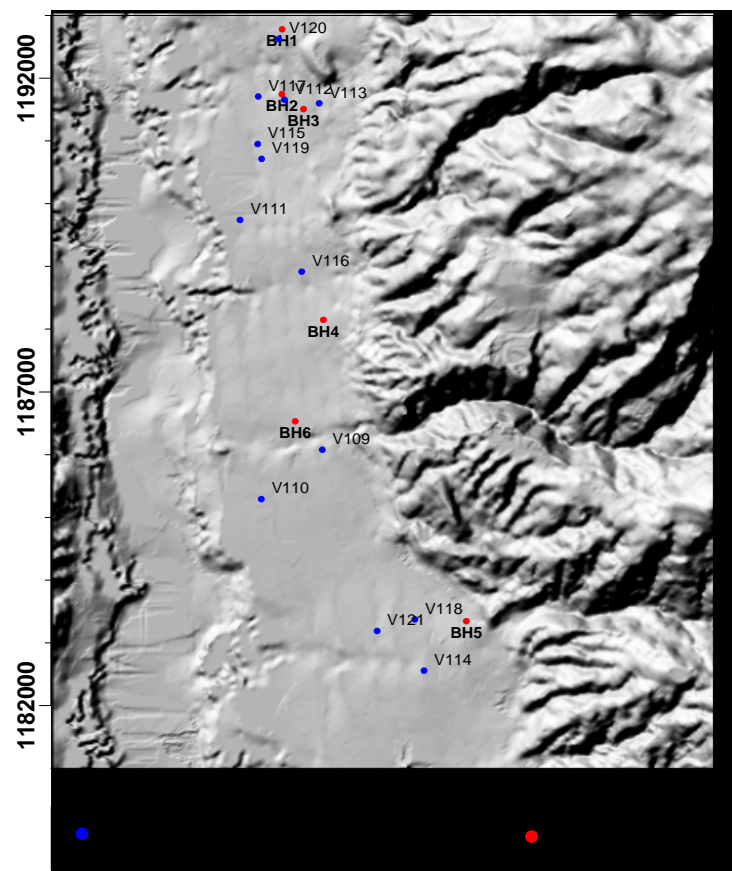

(b)

Figure 3. (a) Location map of VES and Boreholes in the southern part of the study area; (b) Location map of VES and BH in the northern part of study area.

for accurate measurements over a wide range of conditions. It has a maximum power of 18 watts and a manual selection of currents in steps a power up to $100 \mathrm{~mA}$, which provides a range of measurements from $200 \mathrm{~K} \Omega$ down to $0.001 \Omega$. Schlumberger configuration of electrodes was used in the field surveys. The profiles were directed into N-S direction perpendicular to the expected buried stream channel. The maximum current electrodes separation extends up to $1000 \mathrm{~m}$. The increase of electrical electrodes separation lead to rapidly reduced the potential difference to be measured at potential electrodes [14]; therefore the potential electrode distances were increased gradually to get a better signal. The selection of soundings location was governed by the site conditions, free - geophysical noise area, accessibility through cultivated farms and road availability. The apparent resistivity values were obtained by multiplying the field resistance measurements by configuration factor at each of electrodes separation. The calculated apparent resistivity measurements were plotted against half of the current electrode spacing $(\mathrm{AB} / 2)$ on bi-logarithmic scale, a traditional interpretation techniques by curve matching and drawing auxiliary point diagram [15] was applied. Based on this preliminary interpretation, an initial estimation of resistivities and thicknesses of various geo-electrical layers was obtained. These preliminary estimations were later used as a start model incorporating known geology and the available borehole data for a fast computerassisted interpretation RESIST written by [16]. Based on the starting model, the program conducts an iteration process by trying to adjust the theoretical model and its sounding curve with the measured (field) curve. A "best fit" to stop the iteration process may be defined by a computer calculating the root mean square or by the interpreter [14]. The results of interpretation were also compared with the result of purely automatic inversion programs without any assumptions of layering model in which the layering model is obtained directly from a digitized sounding curve [17]. To get a reasonable geological and hydrogeological interpretation of the resistivity measurements, the lithological information of available boreholes were used to calibrate the geo-electrical parameters (Figure 4) and some geoelectrical cross sections were calibrated with the logs of available boreholes (Figures 13, 14 and 16). The optimum objective of applying geo-electrical method is to obtain detailed information about the lateral and vertical distribution of resistivity in the ground. Summary lists of the interpreted geoelectrical models for some VES soundings which are not shown along the geoelectrical cross sections are presented in Table $\mathbf{3}$, while Figures 5-8 show examples of four of VES curves and their geophysical interpretation.

\section{Results and Discussion}

\subsection{Geo-Electrical Cross Sections}

The interpreted Vertical Electrical Soundings data (VES) were used to construct nine geo-electrical cross-sections 
Table 3. Summary list of some interpreted geoelectrical soundings that are not shown along the geoelectrical cross sections (resistivity $(\rho)$ in $\Omega . m$ and thickness $(h)$ in meter $(\mathrm{m})$ ).

\begin{tabular}{|c|c|c|c|c|c|c|c|c|c|c|c|}
\hline VES & $\rho 1$ & $\rho 2$ & $\rho 3$ & $\rho 4$ & $\rho 5$ & $\rho 6$ & h1 & $\mathrm{h} 2$ & h3 & $\mathrm{h} 4$ & h5 \\
\hline 28 & 5 & 35 & 5 & 35 & - & - & 1 & 8 & 33 & - & - \\
\hline 46 & 10 & 20 & 8 & 25 & 15 & - & 3 & 6 & 13 & 44 & - \\
\hline 63 & 250 & 85 & 15 & - & - & - & 3 & 4 & - & - & - \\
\hline 97 & 10 & 8 & 35 & 3 & 10 & 1 & 2 & 4 & 4 & 41 & 22 \\
\hline 99 & 15 & 65 & 15 & - & - & - & 3 & 18 & - & - & - \\
\hline 100 & 15 & 80 & 6 & 40 & - & - & 4 & 16 & 9 & - & - \\
\hline 101 & 20 & 8 & 60 & 90 & 35 & 7 & 2 & 2 & 16 & 5 & 25 \\
\hline 102 & 22 & 90 & 38 & 7 & - & - & 2 & 8 & 20 & - & - \\
\hline 103 & 22 & 90 & 38 & 7 & - & - & 2 & 8 & 20 & - & - \\
\hline 104 & 12 & 5 & 40 & 7 & - & - & 1 & 16 & 60 & - & - \\
\hline 105 & 100 & 40 & 8 & 70 & 9 & - & 2 & 16 & 21 & 62 & - \\
\hline 107 & 34 & 7 & 50 & 4 & - & - & 2 & 26 & 36 & - & - \\
\hline 109 & 65 & 100 & 60 & - & - & - & 3 & 115 & - & - & - \\
\hline 110 & 11 & 64 & 20 & 47 & 3 & - & 3 & 9 & 27 & 50 & - \\
\hline 111 & 25 & 11 & 15 & 7 & 2 & - & 3 & 6 & 87 & 42 & - \\
\hline 114 & 500 & 142 & 65 & 5 & - & - & 5 & 41 & 48 & - & - \\
\hline 115 & 34 & 48 & 5 & 15 & 4 & - & 1 & 3 & 21 & 70 & - \\
\hline 116 & 120 & 63 & 90 & 35 & 16 & 10 & 3 & 12 & 12 & 36 & 32 \\
\hline 120 & 285 & 70 & 150 & 63 & 14 & 9 & 4 & 15 & 23 & 32 & 78 \\
\hline 121 & 19 & 12 & 8 & 12 & 28 & 6 & 2 & 2 & 4 & 3 & 90 \\
\hline
\end{tabular}

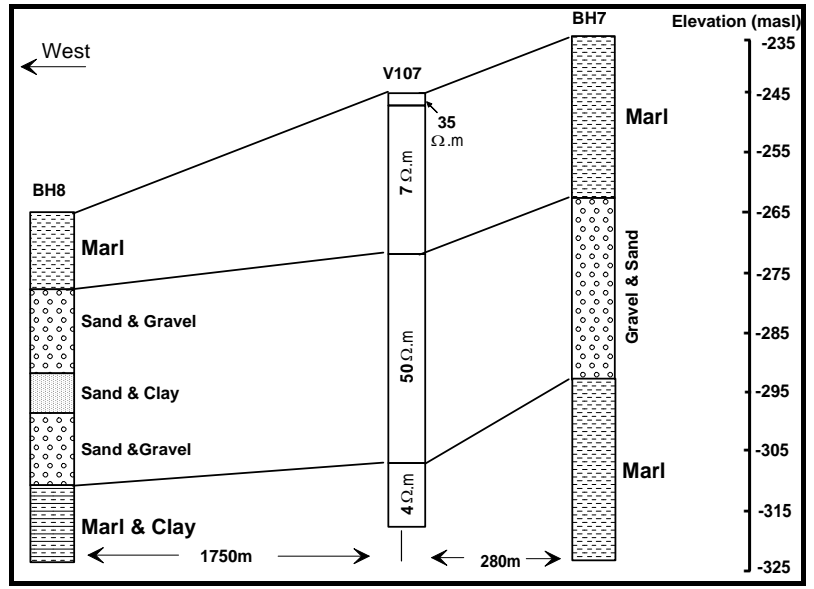

Figure 4. Correlation of the interpreted resistivity sounding $\mathrm{V} 107$ with bore hole data of $\mathrm{BH} 7$ and $\mathrm{BH8}$ (for location of boreholes and V107, see Figure 1).

across the study area. Their locations and extensions are presented in Figure 9 and the constructed geo-electrical cross-sections in Figures 10-18. A detailed inspection of the geo-electrical cross-sections along with the calibration of VES results and borehole data indicates the presence of different predominant lithofacies in the study area, those are: The top soil layer (wide resistivity range 20 - 200 Ohm.m layer); clay, marl, clay with saline water (resistivity $\leq 10$ Ohm.m); sand with silt (10 - 20 Ohm.m); sand and gravel; saturated alluvium (20 - 60 Ohm.m); and unconsolidated deposits, gravel, dry sand where resistivity is larger than $60 \mathrm{Ohm} . \mathrm{m}$.

- Top Soil layer: In the study area, different types of soils have been developed throughout the geological history. Generally, these types reflect the composition and types of the parent rocks over which these soil types have developed. According to the National Soil Mapping Project [18] the soil types dominant in the study area are: Type-1: Randzina and Lithosol with their parent rocks of carbonate. They are shallow, up to $1 \mathrm{~m}$ in depth, and cover the most eastern part of the study area. The VES's encountered along geoelectrical cross-section (A-A'; B-B' Figure 10 and Figure 11 respectively) were performed in area where Randzina and lithosol soil prevail with the results that the top soil of $1-3 \mathrm{~m}$ have high resistivity. Type-2: Soil developed on loss-like sediment; these soils are silty and Loamy with moderate humus in addition to granular and friable gravel [18]. This type of soil occupies the most western part of the study area. The VES's encountered along the geo-electrical crosssections: (E-E'; F-F' and G-G', Figure 14, Figure 15 and Figure 18 respectively). They showed relatively moderate resistivity of $15-30 \mathrm{Ohm} . \mathrm{m}$ for the top 


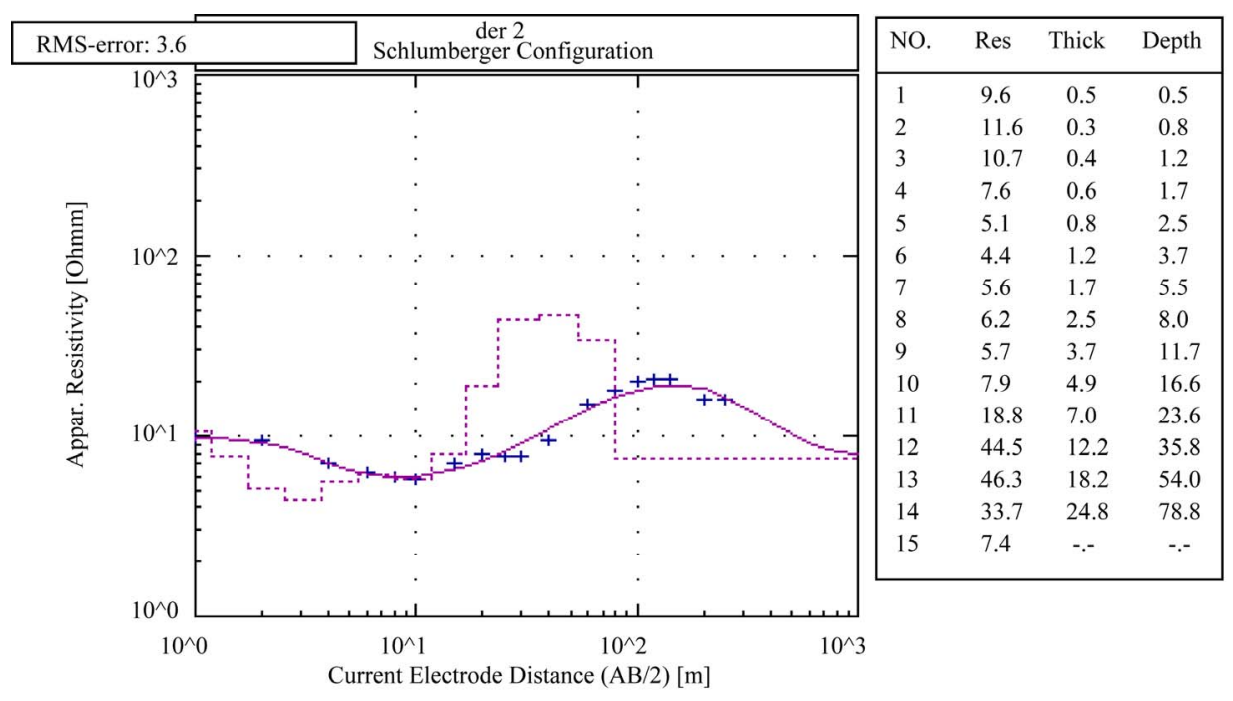

Figure 5. Geo-electric sounding and interpretation of V104.

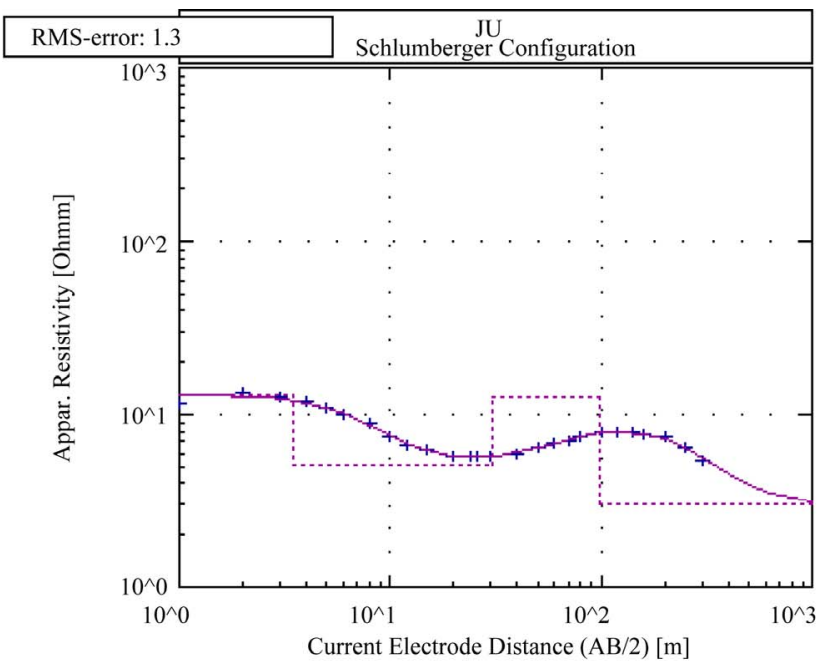

\begin{tabular}{|llll|}
\hline NO. & Res & Thick & Depth \\
\hline 1 & 13.0 & 3.5 & 3.5 \\
2 & 5.1 & 27.2 & 30.7 \\
3 & 12.7 & 66.6 & 97.3 \\
4 & 3.0 &.-- &.-- \\
\hline
\end{tabular}

Figure 6. Geo-electric sounding and interpretation of V106.

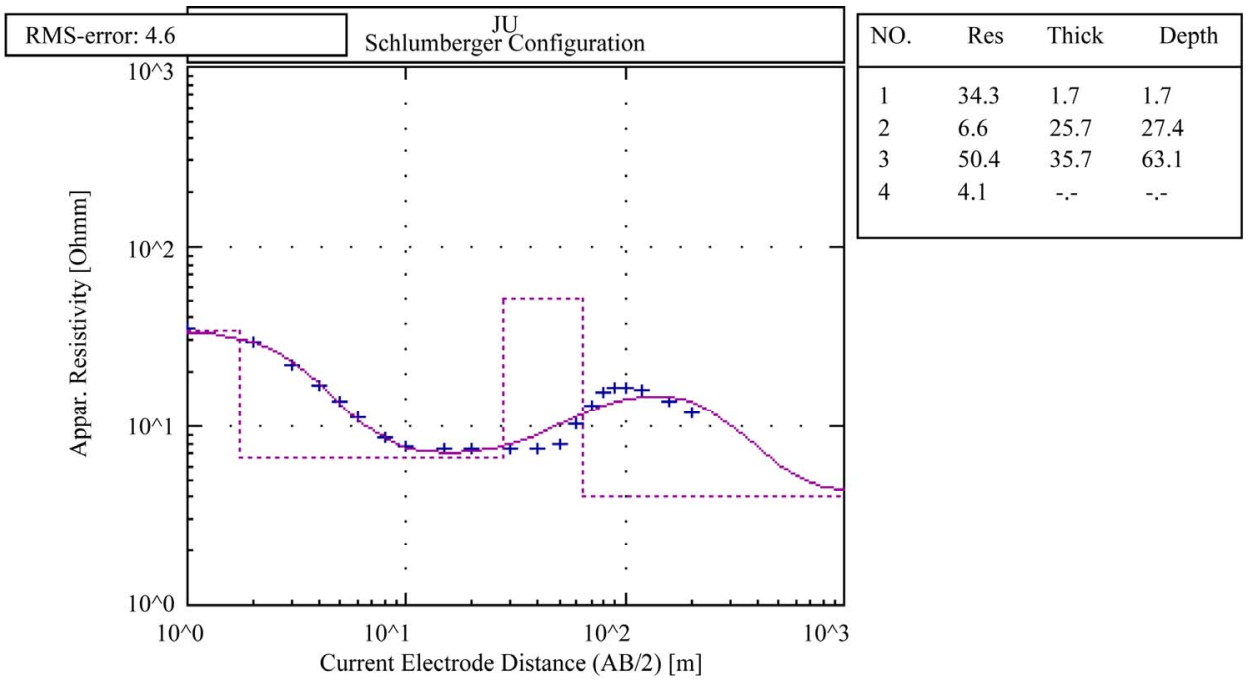

Figure 7. Geo-electric sounding and interpretation of V107. 


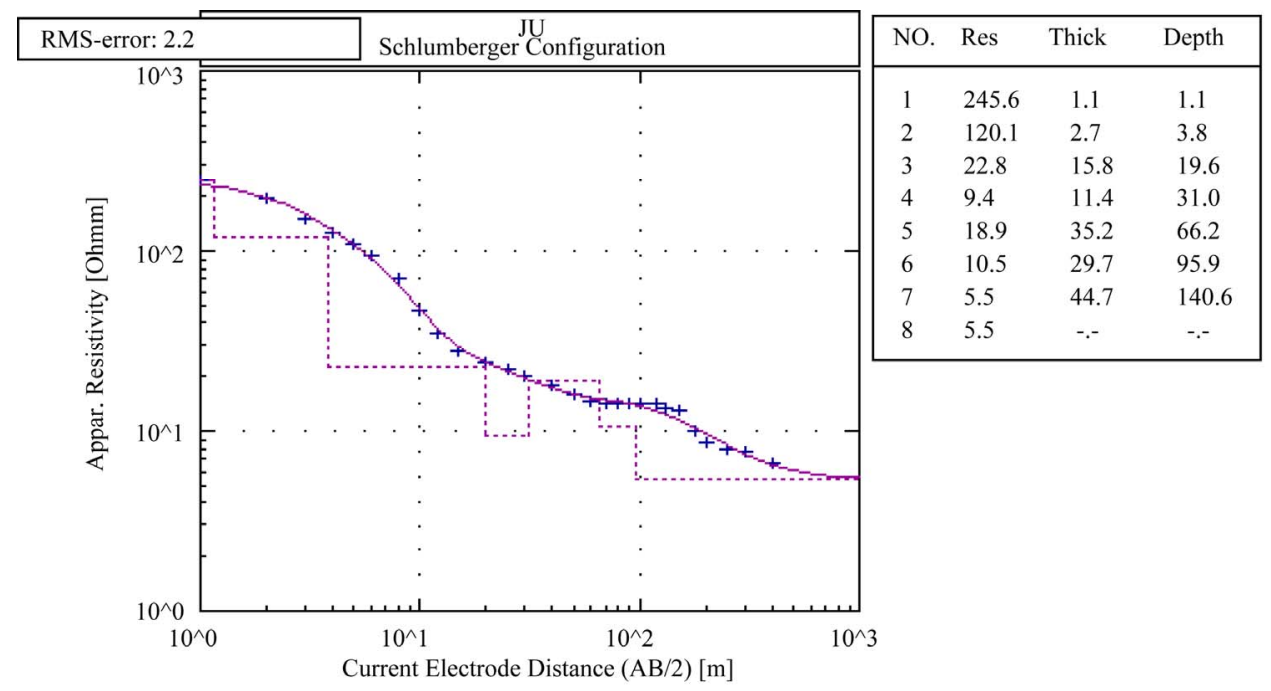

Figure 8. Geo-electric sounding and interpretation of V108.

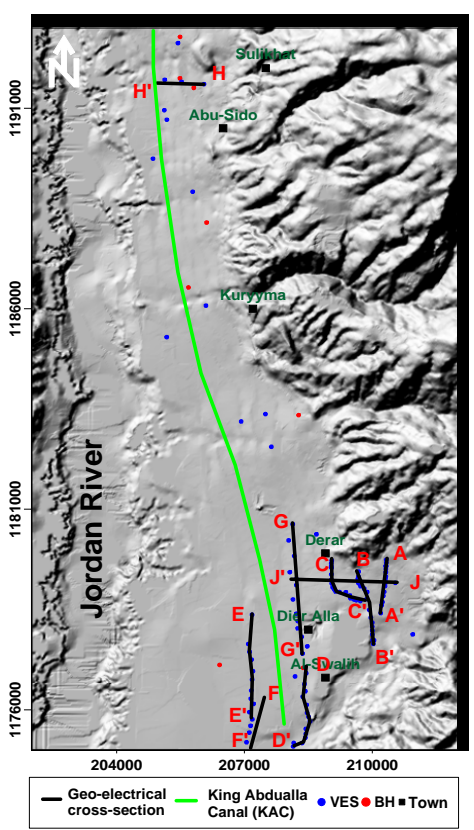

Figure 9. Geo-electrical cross-sections overlying shaded relief map of the study area (see text for explanation).

soil, down to a depth of $2 \mathrm{~m}$. Type-3: Rendzina soils which are developed over gravel fans. They are underlain by gravel and stony horizons [19]. In the study area, they occupy the area lying between Type-1 and Type- 2 .

- Unconsolidated deposits, Gravel and dry Sand: An unconsolidated sandy gravel layer of about 5 to $30 \mathrm{~m}$ with a resistivity of $>60 \mathrm{Ohm} . \mathrm{m}$ is found underlying the soil profile at different sites along the geo-electrical cross-sections in the study area (e.g. $20 \mathrm{~m}$ under V55, V62, V54, V61, V51; 5 to $10 \mathrm{~m}$ under V56; >30 $\mathrm{m}$ under V48, V59, V49, V60 along A-A' geo-electrical cross section Figure 10; $10 \mathrm{~m}$ under V29, V13,

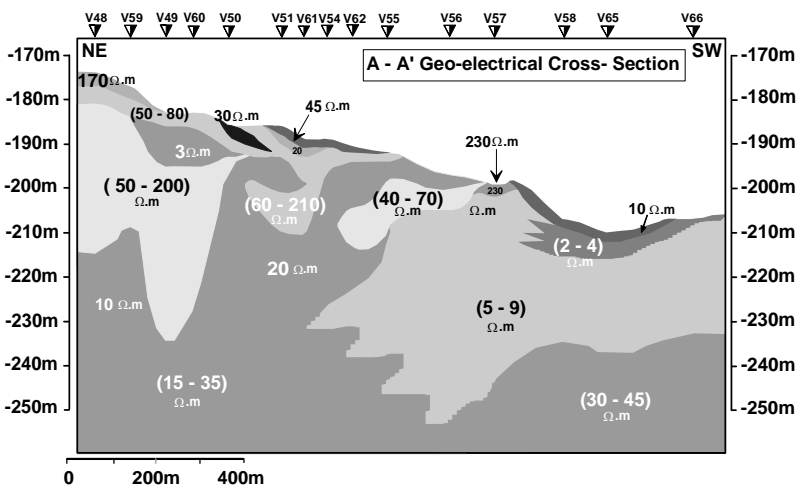

Figure 10. Underground resistivities along geoelectrical cross section A-A'.

V14, V30; 5 - 20 m under V4, V2, V6, V32, V1, V7; $4 \mathrm{~m}$ under V5 along geo-electrical cross-section B-B' Figure 11; 5 - $15 \mathrm{~m}$ under V53, V47, V52 along geo-electrical cross-section C-C' Figure 12; 5 - $20 \mathrm{~m}$ under V76, V77, V78, V79, this zone indicates a probable ancient flow channel of Zarqa river along geo-electrical cross section D-D' Figure 13; 20 - 30 $\mathrm{m}$ under V28a, V62, V6 along the geo-electrical crosssection J-J' Figure 17; 20 - 30 m under V113, V112 in Sulikhat area along the geo-electrical crosssection H-H' Figure 16.

- Marl and Clay layers (Lisan Marl formation): Two principles marly, clayey layer of Lisan-Marl formation with an average resistivity range of $1-10$ Ohm.m has been identified throughout the constructed geoelectrical cross sections. The first layer lies beneath the unconsolidated deposits, gravel dry sand layer and above the water saturated sandy gravel layer (Figure 12, Figure 15 and Figure 13). The second layer lies beneath the water saturated sandy gravel layer and forms the most bottom layer of the 


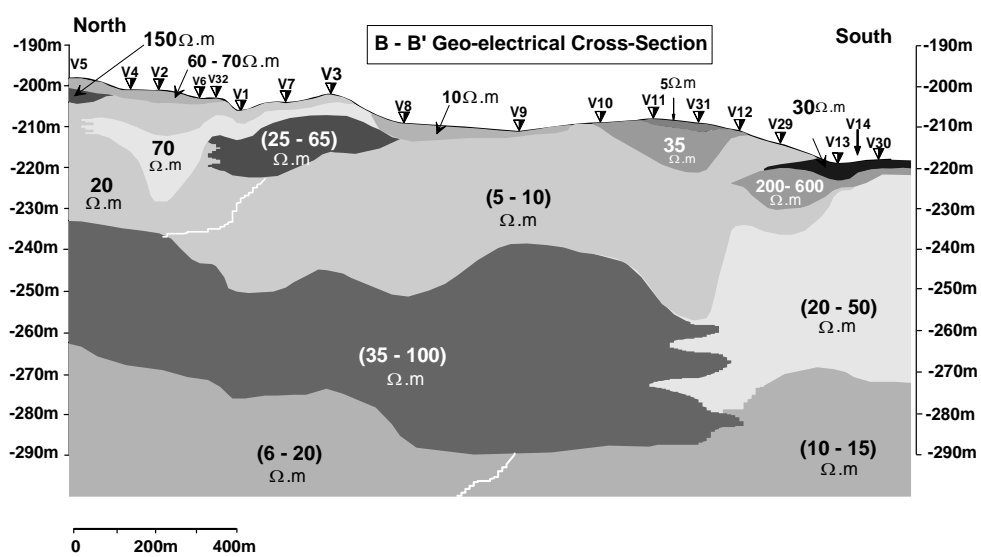

Figure 11. Underground resistivities along geoelectrical cross section B-B'.

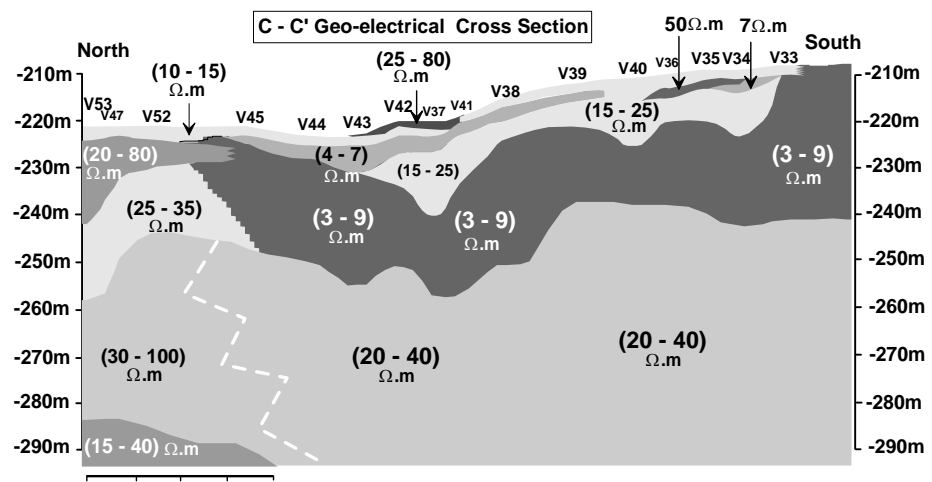

Figure 12. Underground resistivities along geoelectrical cross section C-C'.

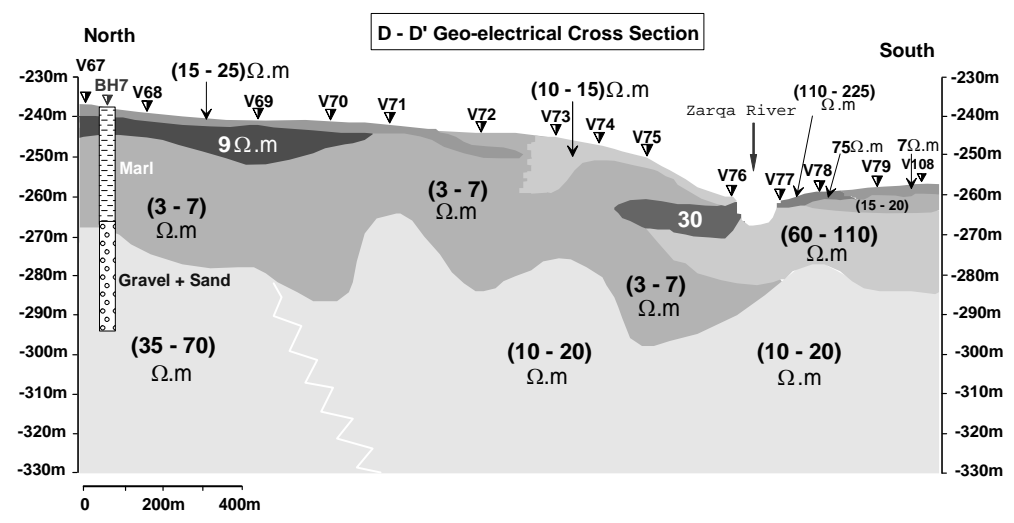

Figure 13. Underground resistivities along geoelectrical cross section D-D'.

whole Jordan Valley (Figure 11, Figure 14 and Figure 15).

- Water Saturated Sandy Gravel layer: This layer forms the major water bearing layer in the Jordan Valley, which has been subjected to over-pumping of its groundwater sources during the past four decades [2]. The average resistivity ranges of this layer were found to be in the range (20 - $60 \mathrm{Ohm} . \mathrm{m})$. It was assigned based on a correlation of different lithological $\log$ data and geoelectrical measurements (Figure 4, Figure 13, Figure 14 and Figure 16). This layer was found along the all geoelectrical cross sections (e.g. 15 - 45 Ohm.m (Figure 10); 20 - 100 Ohm.m (Figure 11) and (Figure 12); 10 - 25 Ohm.m (Figure 18); 35 - 70 Ohm.m (Figure 13); 20 - 35 Ohm.m (Figure 14); 15 - $35 \mathrm{Ohm}$ (Figure 15); 15 - 50 (Figure 17) and 13 - 17 Ohm.m (Figure 16).

\subsection{Iso-Resistivity Contour Maps}

The apparent resistivity $(\rho \mathrm{a})$ at selected half electrode separations $(\mathrm{AB} / 2=20 \mathrm{~m}$ and $\mathrm{AB} / 2=60 \mathrm{~m})$, measured 


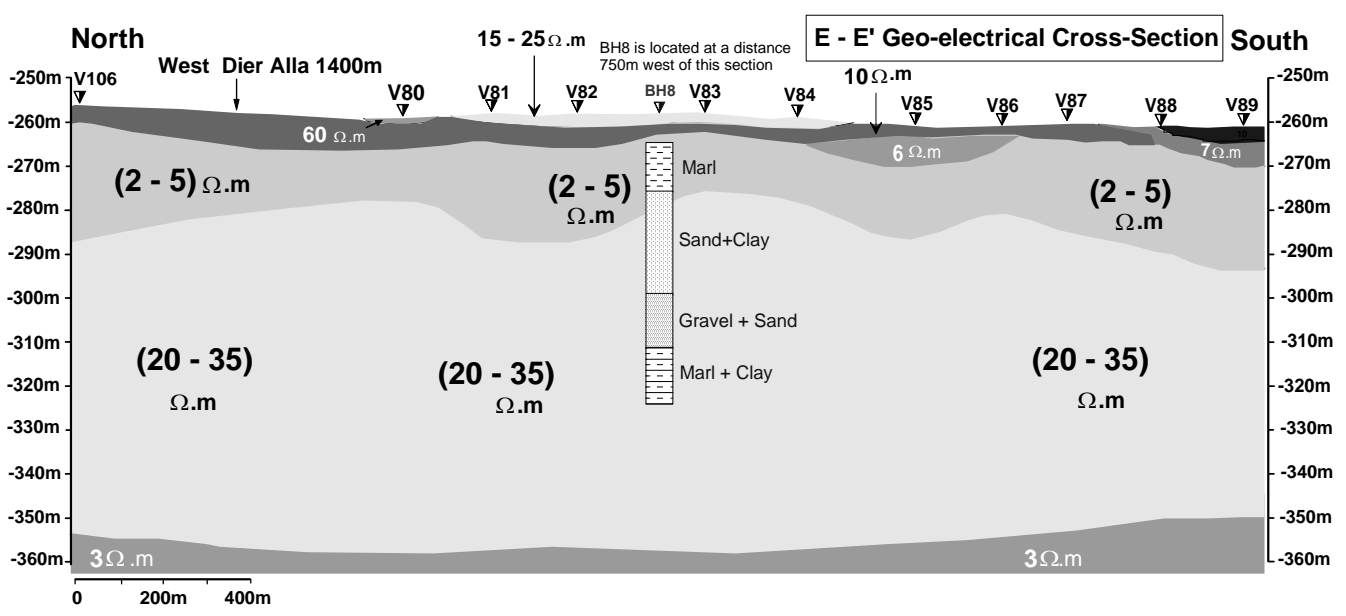

Figure 14. Underground resistivities along geo-electrical cross section E-E'.

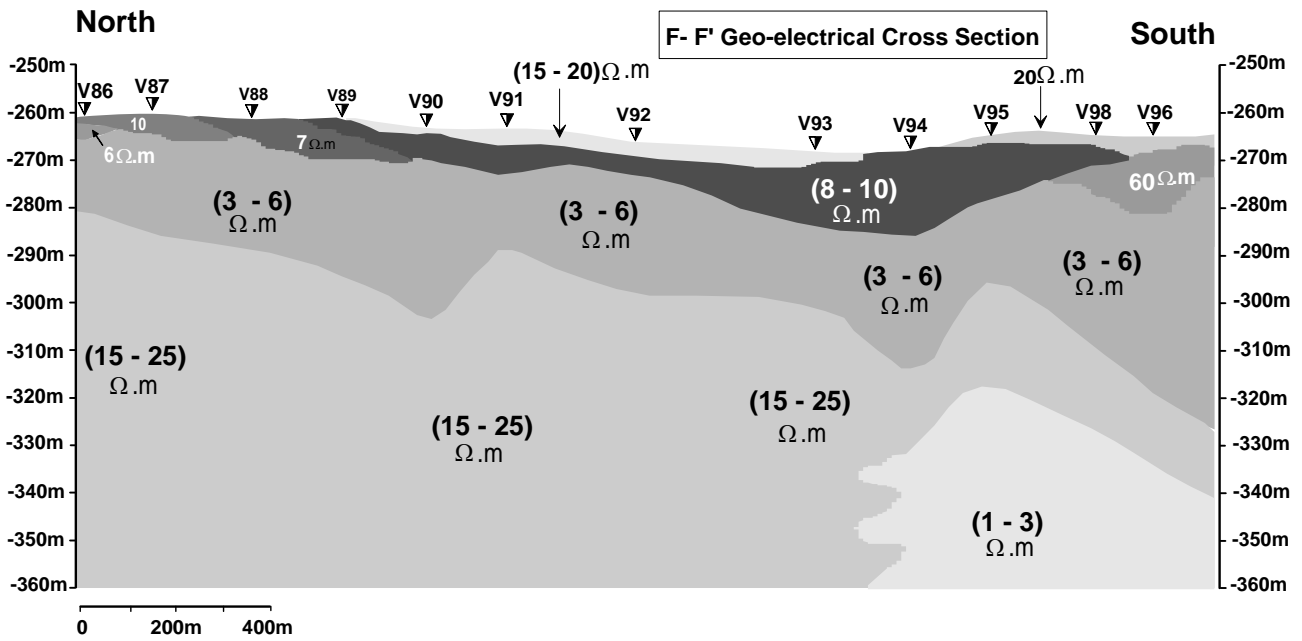

Figure 15. Underground resistivities along geo-electrical cross section F-F'.

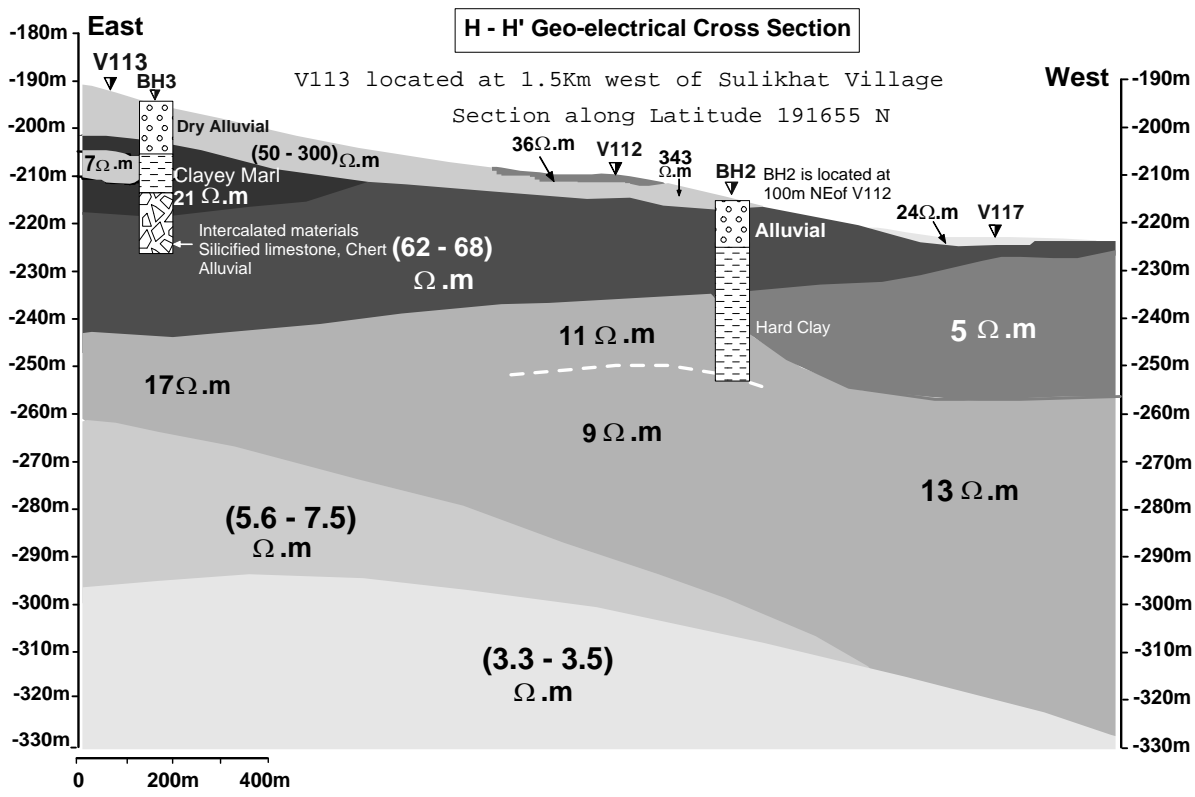

Figure 16. Underground resistivities along geo-electrical cross section H-H'. 


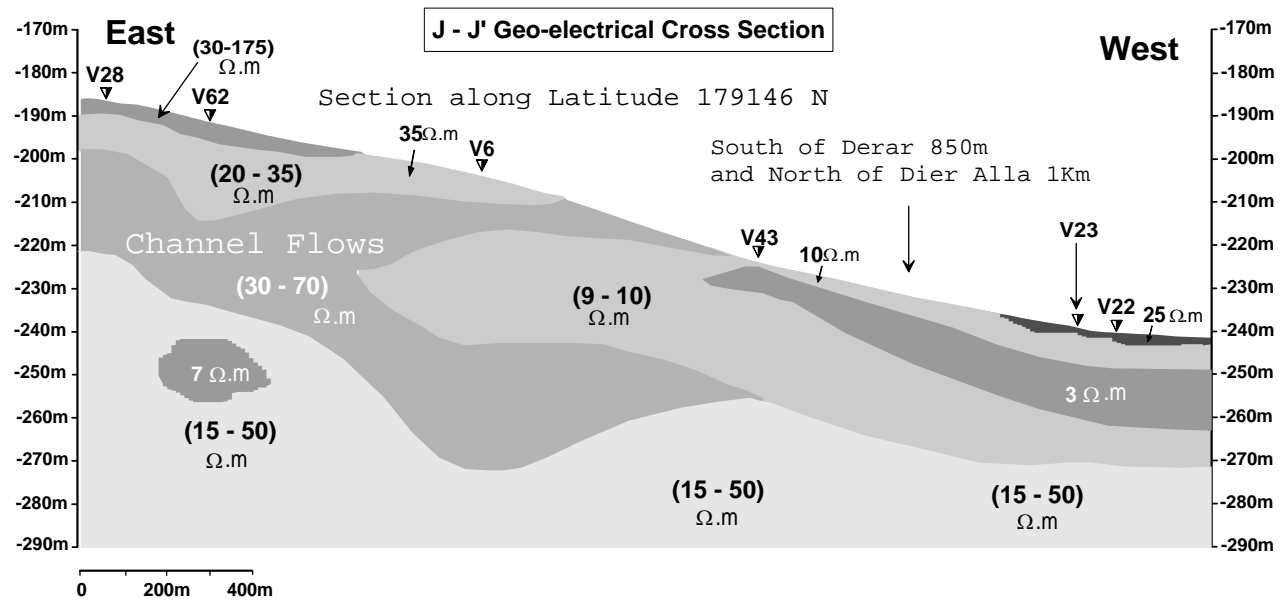

Figure 17. Underground resistivities along geo-electrical cross section J-J'.

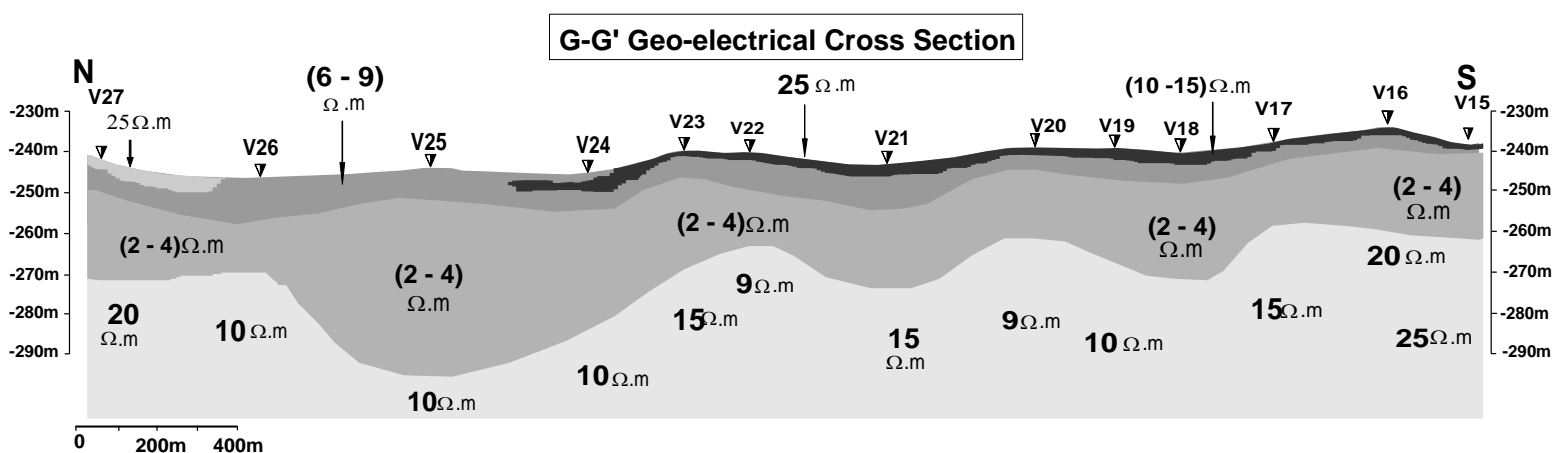

Figure 18. Underground resistivities along geo-electrical cross section G-G'

for all the vertical soundings carried out in the study area, were used to develop an iso-resistivity contouring maps, these are shown in Figure 19(a) and Figure 19(b). The results show that the contour pattern is oriented around, $\mathrm{N}-\mathrm{S}$ with general decreasing values to the west. In the eastern part of the study area, along longitude 208.000, the maps show high values of apparent resistivity relative to the western part, this clearly indicating the presence of unconsolidated, dry sand, gravel alluvial deposits at depths corresponding to those electrode separations. The low apparent resistivities values of about $10 \mathrm{Ohm} . \mathrm{m}$ exist along the western margin of the study area indicate to the presence of very saline clays of the Lisan marl formations.

\section{Hydrochemical Study}

A major concern in artificial recharge and underground water storage studies is the resulting water chemistry when surface or treated water joins the groundwater system and mixes with it. Mixing processes generally shift the water chemistry of the two mixed solutions into a middle state between them depending on the mixing ratios [20]. In the course of this study five water samples from wells and springs in the study area and its sur- roundings, besides KAC water of one year samples which were collected and analyzed for their major physical and chemical constituents. The results of analyses are listed in Tables 4-5 respectively. The objective of this section is to study the quality of surface and groundwater, besides thermodynamics and mixing process for water underground storage purposes.

\section{Saturation Indices and Water-Water and Water-Rock Interaction}

The saturation states of minerals in the groundwater of the study area were calculated using the equations of thermodynamic equilibrium states to assess the dissolution/precipitation of the groundwater. The calculations were done using the software HYDROWIN Version.3 [21]. Tables 6-7 list the results of measured chemical and physical constituents after mixing of groundwater and KAC at different ratios and Tables 8-10 lists the results of calculation and saturation indices. The results indicate that the groundwater is under-saturated with respect to Calcite, Dolomite, Gypsum and Anhydrite and strongly under-saturated with respect to Halite. This means that the water is capable to dissolving Calcite, Dolomite, Gypsum, Anhydrite and Halite. But since the 


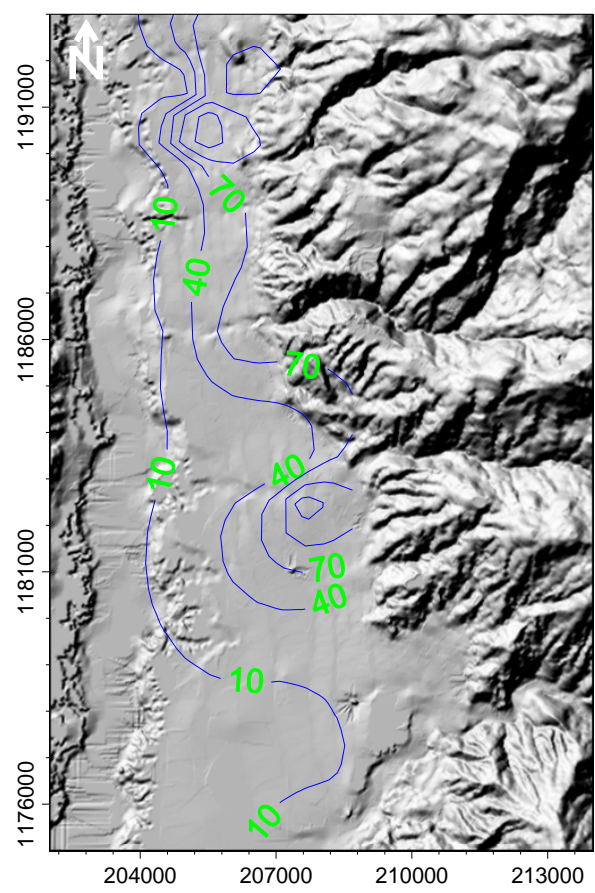

(a)

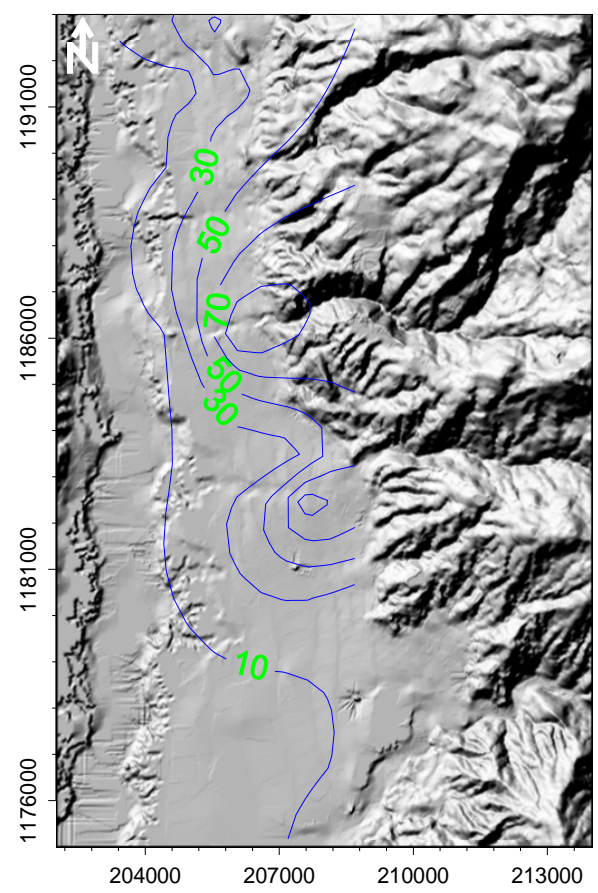

(b)

Figure 19. (a) Iso-Resistivity map (Ohm.m) overlying shaded relief map of the study area at electrode separation $(\mathrm{AB} / 2=\mathbf{2 0}$ m); (b) Iso-Resistivity map (Ohm.m) overlying shaded relief map of the study area at electrode separation $(\mathrm{AB} / 2=60 \mathrm{~m})$.

Table 4. Chemical composition of groundwater resources in the study area (meq/l).

\begin{tabular}{ccccccccccccc}
\hline No & Source (well ID) & $\begin{array}{c}\mathrm{EC} \\
\mu \mathrm{S} / \mathrm{cm}\end{array}$ & $\begin{array}{c}\mathrm{T} . \mathrm{D} . \mathrm{S} \\
\mathrm{mg} / 1\end{array}$ & $\mathrm{pH}$ & $\begin{array}{c}\mathrm{Ca}^{2+} \\
\mathrm{meq} / 1\end{array}$ & $\begin{array}{c}\mathrm{Mg}^{2+} \\
\mathrm{meq} / 1\end{array}$ & $\begin{array}{c}\mathrm{Na}^{+} \\
\mathrm{meq} / 1\end{array}$ & $\begin{array}{c}\mathrm{K}^{+} \\
\text {meq/1 }\end{array}$ & $\begin{array}{c}\mathrm{Cl}^{-} \\
\mathrm{meq} / 1\end{array}$ & $\begin{array}{c}\mathrm{SO}_{4}^{-} \\
\mathrm{meq} / 1\end{array}$ & $\begin{array}{c}\mathrm{HCO}_{3}^{-} \\
\mathrm{meq} / 1\end{array}$ & $\begin{array}{c}\mathrm{NO}_{3}^{-} \\
\mathrm{meq} / 1\end{array}$ \\
\hline 1 & SULK n4 & 628 & 316.4 & 7.10 & 1.80 & 4.20 & 0.96 & 0.15 & 1.8 & 0.57 & 3.60 & 0.04 \\
2 & SULK n5 & 669 & 376.6 & 7.48 & 2.33 & 4.40 & 1.20 & 0.14 & 1.65 & 0.43 & 4.50 & 0.43 \\
3 & SULK n8 & 536 & 396 & 7.32 & 1.60 & 2.30 & 1.99 & 0.14 & 3.80 & 0.60 & 3.20 & 0.50 \\
4 & KUR n2 & 750 & 414.3 & 7.30 & 1.50 & 4.10 & 2.38 & 0.30 & 2.18 & 1.25 & 4.10 & 0.15 \\
5 & KUR n1 & 1095 & 605.2 & 7.20 & 3.46 & 5.81 & 1.87 & 0.47 & 3.19 & 2.50 & 5.35 & 0.20 \\
& AVERAGE & 736 & 421.7 & 7.28 & 2.13 & 4.16 & 1.68 & 0.23 & 2.52 & 1.07 & 4.15 & 0.26 \\
\hline
\end{tabular}

Table 5. Maximum, minimum and average composition of King Abdullah Canal (KAC) water one year average (meq/l), at two sites.

\begin{tabular}{|c|c|c|c|c|c|c|c|c|c|c|c|}
\hline Source (site) & & $\begin{array}{c}\text { E.C } \\
\mu \mathrm{S} / \mathrm{cm}\end{array}$ & $\mathrm{pH}$ & $\mathrm{Ca}^{2+} \mathrm{meq} / 1$ & $\begin{array}{l}\mathrm{Mg}^{2+} \\
\mathrm{meq} / 1\end{array}$ & $\begin{array}{l}\mathrm{Na}^{+} \\
\mathrm{meq} / 1\end{array}$ & $\begin{array}{c}\mathrm{K}^{+} \\
\mathrm{meq} / 1\end{array}$ & $\begin{array}{c}\mathrm{Cl}^{-} \\
\mathrm{meq} / 1\end{array}$ & $\begin{array}{l}\mathrm{SO}_{4}^{2-} \\
\mathrm{meq} / 1\end{array}$ & $\begin{array}{l}\mathrm{HCO}_{3}^{-} \\
\mathrm{meq} / 1\end{array}$ & $\mathrm{NO}_{3}^{-} \mathrm{meq} / \mathrm{l}$ \\
\hline \multirow{3}{*}{$\begin{array}{c}\text { Mixture of KAC \& Ziglab } \\
\text { Dam Water }\end{array}$} & Max & 1111 & 8.30 & 4.08 & 6.22 & 4.78 & 0.20 & 5.48 & 2.29 & 5.06 & 0.30 \\
\hline & Min & 447 & 7.93 & 1.79 & 1.39 & 0.95 & 0.07 & 1.30 & 0.72 & 2.01 & 0.00 \\
\hline & Avg. & 939 & 8.12 & 2.90 & 2.60 & 3.23 & 0.16 & 3.63 & 1.46 & 3.24 & 0.12 \\
\hline \multirow{3}{*}{ KAC at Deir Alla area } & Max & 1118 & 8.33 & 3.98 & 5.63 & 4.35 & 0.25 & 6.07 & 2.01 & 4.87 & 0.28 \\
\hline & Min & 466 & 7.62 & 1.66 & 1.39 & 1.30 & 0.10 & 1.51 & 0.37 & 1.93 & 0.00 \\
\hline & Avg. & 937 & 8.03 & 2.82 & 2.75 & 3.32 & 0.17 & 3.99 & 1.34 & 3.30 & 0.12 \\
\hline
\end{tabular}


Table 6. Mixing results of groundwater with KAC average water in different ratios.

\begin{tabular}{|c|c|c|c|c|c|c|c|}
\hline Solution 1 & \multicolumn{7}{|c|}{ Groundwater Average } \\
\hline Solution 2 & \multicolumn{7}{|c|}{ KAC Average } \\
\hline \multicolumn{8}{|c|}{ Percentage of solution 1 in target solution $67 \%$ - $33 \%$} \\
\hline Solution 1 & 1.00 & 0.67 & 0.58 & 0.50 & 0.42 & 0.33 & 0.00 \\
\hline Solution 2 & 0.00 & 0.33 & 0.42 & 0.50 & 0.58 & 0.67 & 1.00 \\
\hline $\mathrm{Na}^{+}(\mathrm{meq} / \mathrm{l})$ & 1.68 & 2.23 & 2.36 & 2.50 & 2.64 & 2.77 & 3.32 \\
\hline $\mathrm{K}^{+}(\mathrm{meq} / \mathrm{l})$ & 0.24 & 0.22 & 0.21 & 0.20 & 0.20 & 0.19 & 0.17 \\
\hline $\mathrm{Ca}^{2+}(\mathrm{meq} / \mathrm{l})$ & 2.14 & 2.37 & 2.42 & 2.48 & 2.54 & 2.59 & 2.82 \\
\hline $\mathrm{Mg}^{2+}(\mathrm{meq} / \mathrm{l})$ & 4.16 & 3.69 & 3.57 & 3.46 & 3.34 & 3.22 & 2.75 \\
\hline $\mathrm{Cl}^{-}(\mathrm{meq} / \mathrm{l})$ & 2.52 & 3.01 & 3.13 & 3.26 & 3.38 & 3.50 & 3.99 \\
\hline $\mathrm{HCO}_{3}^{-} \quad(\mathrm{meq} / \mathrm{l})$ & 4.15 & 3.87 & 3.80 & 3.73 & 3.65 & 3.58 & 3.30 \\
\hline $\mathrm{SO}_{4}^{2-} \quad(\mathrm{meq} / \mathrm{l})$ & 1.07 & 1.16 & 1.18 & 1.21 & 1.23 & 1.25 & 1.34 \\
\hline $\mathrm{pH}$ & 7.28 & 7.42 & 7.46 & 7.51 & 7.56 & 7.62 & 8.03 \\
\hline
\end{tabular}

Table 7. Mixing results of groundwater with KAC maximum water in different ratios.

\begin{tabular}{|c|c|c|c|c|c|c|c|}
\hline Solution 1 & \multicolumn{7}{|c|}{ Groundwater Average } \\
\hline Solution 2 & \multicolumn{7}{|c|}{ KAC Maximum } \\
\hline \multicolumn{8}{|c|}{ Percentage of solution 1 in target solution $67 \%$ - $33 \%$} \\
\hline Solution 1 & 1.00 & 0.67 & 0.58 & 0.50 & 0.42 & 0.33 & 0.00 \\
\hline Solution 2 & 0.00 & 0.33 & 0.42 & 0.50 & 0.58 & 0.67 & 1.00 \\
\hline $\mathrm{Na}^{+}(\mathrm{meq} / \mathrm{l})$ & 1.68 & 2.57 & 2.79 & 3.02 & 3.24 & 3.46 & 4.35 \\
\hline $\mathrm{K}^{+}(\mathrm{meq} / \mathrm{l})$ & 0.24 & 0.24 & 0.24 & 0.24 & 0.25 & 0.25 & 0.25 \\
\hline $\mathrm{Ca}^{2+}(\mathrm{meq} / \mathrm{l})$ & 2.14 & 2.75 & 2.91 & 3.06 & 3.21 & 3.37 & 3.98 \\
\hline $\mathrm{Mg}^{2+}(\mathrm{meq} / \mathrm{l})$ & 4.16 & 4.65 & 4.77 & 4.90 & 5.02 & 5.14 & 5.63 \\
\hline $\mathrm{Cl}^{-}(\mathrm{meq} / \mathrm{l})$ & 2.52 & 3.71 & 4.00 & 4.30 & 4.59 & 4.89 & 6.07 \\
\hline $\mathrm{HCO}_{3}^{-} \quad($ meq $/ \mathrm{l})$ & 4.15 & 4.39 & 4.45 & 4.51 & 4.57 & 4.63 & 4.87 \\
\hline $\mathrm{SO}_{4}^{2-} \quad(\mathrm{meq} / \mathrm{l})$ & 1.07 & 1.38 & 1.46 & 1.54 & 1.62 & 1.70 & 2.01 \\
\hline $\mathrm{pH}$ & 7.28 & 7.44 & 7.49 & 7.54 & 7.61 & 7.69 & 8.33 \\
\hline
\end{tabular}

Table 8. Saturation Indices of KAC water and groundwater in the study area.

\begin{tabular}{lccccc}
\hline Station ID & \multicolumn{3}{c}{ Saturation Indices } & & Halite \\
\cline { 2 - 6 } & Anhydrite & Calcite & Dolomite & Gypsum & -9.38 \\
D. Allah Avg & -4.77 & -2.38 & -4.49 & -4.53 & -9.09 \\
D. Allah Max & -4.48 & -1.79 & -3.15 & -4.24 & -10.21 \\
D. Allah Min & -5.53 & -3.23 & -6.26 & -5.29 & -9.88 \\
GW Avg & -4.99 & -3.14 & -5.72 & -4.20 & -9.73 \\
KURA n1 & -4.44 & -2.92 & -5.33 & -4.84 & -9.79 \\
KURA n2 & -5.08 & -3.28 & -5.85 & -5.10 & -10.27 \\
SULK n4 & -5.34 & -3.46 & -6.26 & -5.12 & -10.21 \\
SULK n5 & -5.35 & -2.87 & -5.19 & -5.11 & -9.62 \\
SULK n8 & -5.35 & -3.33 & & & \\
\hline
\end{tabular}


Table 9. Saturation indices of average groundwater (AVG GW) to maximum surface water (Max SW) in the study area.

\begin{tabular}{cccccc}
\hline Sample ID & \multicolumn{4}{c}{ Saturation Indices } \\
\cline { 2 - 6 } AVG GW to Max SW & Anhydrite & Calcite & Dolomite & Gypsum & Halite \\
\hline 1 to 0 & -4.479 & -1.789 & -3.144 & -4.242 & -9.089 \\
2 to 1 & -4.616 & -2.503 & -4.540 & -4.379 & -9.281 \\
1 to 1 & -4.694 & -2.702 & -4.917 & -4.457 & -9.396 \\
1 to 2 & -4.782 & -2.856 & -5.202 & -4.545 & -9.529 \\
0 to 1 & -4.992 & -3.144 & -5.716 & -4.755 & -9.878 \\
\hline
\end{tabular}

Table 10. Saturation indices of average surface water and groundwater in the study area.

\begin{tabular}{cccccc}
\hline Station ID & \multicolumn{5}{c}{ Saturation Indices } \\
\hline GW to SW (averages) & Anhydrite & Calcite & Dolomite & Gypsum & Halite \\
\hline 0 to 1 & -4.770 & -2.382 & -4.492 & -4.533 & -9.382 \\
1 to 0 & -4.993 & -3.144 & -5.716 & -4.755 & -9.878 \\
1 to 1 & -4.874 & -2.898 & -5.368 & -4.637 & -9.594 \\
1 to 2 & -4.840 & -2.786 & -5.195 & -4.600 & -9.517 \\
2 to 1 & -4.912 & -2.991 & -5.507 & -4.675 & -9.679 \\
\hline
\end{tabular}

alluvial aquifer does not contain in its matrix Gypsum, Halite or Anhydrite, the water does and will not have the opportunity to dissolve these minerals as long as it stays in that type of aquifer. Mixing of water of KAC with the average groundwater type of different ratios, (Tables 8-9) indicate that the water after mixing will be still under-saturated with respect of Calcite, Dolomite, Gypsum and Anhydrite and strongly with respect to Halite. It will not only be saturated but it will remain in an under-saturated states. The final result is then mixing of KAC water with the groundwater type found in the study area will not result in any major dissolution/ precipitation reactions within the rock matrix, other than those taking place in a very slow process lasting hundreds to thousands of years.

\section{Summary and Conclusions}

A part of the municipal water supply of north Jordan comes from King Abdullah Canal (KAC) which also supplies irrigation water to farmers in the Jordan Valley area. During the dry season the Canal waters can not supply both municipal and irrigation water due to the water shortages. In addition, sometimes the Canal water witnesses pollution events lasting for days, during which a major drinking water supply in Jordan is interrupted with no substitute. In this article creating water storage in the underground along the Canal (KAC) is studied to store water during times of excess availability in King Abdullah Canal (KAC) for uses in times of water shortage for emergency causes, especially pollution accidents the Canal water. The geology and especially the underlying rocks building the area were mapped and geoelectrically investigated to define the capable rocks for storage and their extensions, the results of geo-electrical profiling were also tuned using geologic well logs.

Mixing processes of the Canal water and the existing groundwater bodies and the water/rocks interaction were also studied. The results show that there is an immense underground space in the area of Deir Alla to store a few million cubic meters of water in the underground that the recharge of groundwater will not negatively affect the existing groundwater quality or the recharge water quality and that water rock interaction will not result in any major precipitation or dissolution of minerals.

The study recommends other geophysical studies such as gravity or electromagnetic surveys to verify the geoelectric and geological findings and to drill small diameter boreholes to depths of a few tens of meters to study the hydraulic properties of the underlying strata. This will enable going into the implementation stage of the artificial recharge project, which also might bring about improvements in the quality of King Abdullah Canal (KAC) water, which will be recharged into the alluvial aquifer as a results of self-purification.

\section{Acknowledgements}

The Authors would like to thank the Federal Ministry of Education and Research of Germany for the financial support of this study within SMART-2 Project. Special thanks are due to Prof. Heinz Hotzl the coordinator of SMART-2 Project for his continuous support and encouragement.

\section{REFERENCES}

[1] E. N. Salameh, "The Potential of Groundwater Artificial 
Recharge in the Jordan Valley Area/Jordan: Selected Contributions to Applied Geology in the Jordan Rift Valley," Freiberger Forschungshefte C494, Freiberg, Vol. 1, No. 2, 2001, pp. 63-81.

[2] H. R. Al-Amoush, "Hydro-Geophysical Investigations for the Purposes of Groundwater Artificial Recharge in the Jordan Valley Area," Ph.D. Dissertation, University of Jordan, Amman, 2006.

[3] E. Salameh, H. Al-Amoush, H. Jasim, B. Sagarat and M. El-Fawwaz, "Underground Water Storage along King Abdullah Canal, A Means to Control Water Pollution and to Cope with Temporary Water Shortages," Final Report for MWI, Amman, 2009.

[4] Ministry of Water and Irrigation (MWI) Open Files, Jordan, 2011.

[5] Department of Metrology (DOM) Open Internal Reports, Amman, 2011.

[6] E. Salameh, "Water Quality Degradation in Jordan," 1st Edition, Friedrich Elbert Stifing (FES) and Royal Society for Conservation of Nature (RSCN), Amman, 1996.

[7] S. M. McDonald and Partners in Cooperation with Hunting Geological Survey Limited, "East Bank Water Resources," Ministry of Water and Irrigation, Amman, Jordan, Vol. 5, 1965, p. 512.

[8] Natural Resources Authority (NRA) Open Files, Jordan 2011.

[9] J. Sahawneh, "Geology and Structural Interpretation of the Area NE of the Dead Sea," M.Sc. Dissertation, Yarmouk University, Irbid, 1991.

[10] F. Bender, "Geology of Jordan," Gebrueder Borntraeger, Berlin, 1974, $196 \mathrm{p}$.

[11] A. Abed, "Geology of Jordan (in Arabic)," Al-Nahda Al-Islamiah Library, Amman, 1982, 232 p.

[12] F. Bender, "Geologie Von Jordanian," Beitrage zur
Regionalen der arde, Gebruder Borntraeger, Berlin, 1968, $230 \mathrm{p}$.

[13] Japan International Cooperation Agency (JICA), "The Study on Brackish Groundwater Desalinization in Jordan Valley," Yachiyo Engineering Co., Ltd, and Mitsu Mineral Development Engineering Co., Ltd., Tokyo, 1965, $318 \mathrm{p}$.

[14] R. Kirsch and K. Ernstson, "Geoelectrical Methods," In: R. Kirsch, Ed., Groundwater Geophysics, a Tool for Hydrogeology, Germany, 2006, pp. 85-116.

[15] E. Orenella and H. M. Mooney, "Master Tables and Curves for Vertical Electrical Sounding over Layered Structures," Interciencia, Madrid, 1966, 34 p.

[16] B. P. A. Vander Velpen and R. J. Sporry, "RESIST. A Computer Program to Process Resistivity Sounding Data on PC Compatibles," Computer and Geosciences, Vol. 19, No. 5, 1993, pp. 691-703. doi:10.1016/0098-3004(93)90102-B

[17] A. Zohdy and R. J. Bisdorf, "Programs for the Automatic Processing and Interpretation of Schlumberger Sounding curves in Quick Basic. U.S.G.S," Open File Report, 89-137-2, 1989, 64 p.

[18] Ministry of Agriculture (MOA) Open Internal Reports, Jordan, 1993.

[19] A. F. Hamadeh, "Quality Changes of Infiltrated RAINWATER in Soils for a Profile Extending from Deir-Alla to Safawi," M.Sc. Dissertation, University of Jordan, 2000.

[20] A. L. Bloom, "Geomorphology a Systematic Analysis of Late Cenozoic Land Forms," Prentice Hall, New Jersey, 1978.

[21] L. Calmbach, "HYDROWIN Software Version 3," Institute de Mineralogy, Lausanne, 1995. 